\title{
Variations in near-saturated hydraulic conductivity of arable mineral topsoils in south-western and central-eastern Finland
}

\author{
Riikka Keskinen ${ }^{1}$, Mari Räty², Janne Kaseva ${ }^{1}$ and Jari Hyväluoma ${ }^{1,3}$ \\ ${ }^{1}$ Natural Resources Institute Finland (Luke), Tietotie 4, FI-31600 Jokioinen, Finland \\ ${ }^{2}$ Natural Resources Institute Finland (Luke), Halolantie 31 A, 71750 Maaninka, Finland \\ ${ }^{3}$ Häme University of Applied Sciences (HAMK), Mustialantie 105, 31310 Mustiala, Finland \\ e-mail: riikka.keskinen@luke.fi
}

\begin{abstract}
Soil hydraulic properties play an important role in determining the level of crop productivity and the extent of environmental loading. Consequently, measurement of near-saturated soil hydraulic conductivity $(\mathrm{K}(\mathrm{h}))$ by tension infiltrometer $(\mathrm{TI})$ is an interesting technique. To provide reference values for near-saturated $\mathrm{K}(\mathrm{h})$ in arable mineral topsoils of Finland and to investigate variability in these values caused by tillage, antecedent soil moisture content and earthworm burrows, field measurements were conducted in south-western and central-eastern Finland using the $\mathrm{TI}$ technique, at supply pressure head $-6,-3$, and $-1 \mathrm{~cm}$. The range of near-saturated $\mathrm{K}(\mathrm{h})$ values obtained was $0.02-12.6 \mathrm{~mm} \mathrm{~h}^{-1}$ at $-6 \mathrm{~cm}, 0.30-85.9 \mathrm{~mm} \mathrm{~h}^{-1}$ at $-3 \mathrm{~cm}$, and $2.55-250 \mathrm{~mm} \mathrm{~h}^{-1}$ at $-1 \mathrm{~cm}$. At $-6 \mathrm{~cm}$ pressure head, clay soils tended to show lower values than coarser-structured soils, but the order was reversed at $-1 \mathrm{~cm}$. The spatial variation in near-saturated $\mathrm{K}(\mathrm{h})$ was moderate and was exceeded by the temporal variation.
\end{abstract}

Key words: infiltration, hydraulic conductivity, tension infiltrometer, boreal mineral soil

\section{Introduction}

The flow of water into and within soil governs several critical ecosystem functions, including soil moisture storage, groundwater recharge, regulation of gas flows, and transport of solutes and particulate materials (e.g. Nielsen et al. 1986, Adhikari and Hartemink 2016). In land under agricultural use, soil hydraulic properties thus play a major role in determining both the level of crop productivity and the extent of environmental loading. Efficient infiltration of precipitation or irrigation into soil prevents surface runoff and erosion, and ensures an adequate supply of water and nutrients to plants (Gray and Norum 1967). On the other hand, preferential flow via macropores reduces the filtering and buffering functions of the soil matrix and may promote subsurface leaching of nutrients and contaminants through field drains (Beven and Germann 2013). Thus in soil quality assessment schemes, a measure of water infiltration rate is frequently included among the selected indicators (Arshad and Martin 2002, Bünemann et al. 2018).

The capacity of a soil for water infiltration, i.e. soil hydraulic conductivity, is generally determined in saturated state (all pores water-filled) by monitoring the flow rate under a constant or falling positive hydraulic head (Angulo-Jaramillo et al. 2016). However, during recent decades, measurements of unsaturated or near-saturated soil hydraulic conductivity by tension infiltrometers (TI) have also been extensively used (Angulo-Jaramillo et al. 2000, Jarvis et al. 2013). In the method, unconfined measurements of infiltration rates are carried out at different negative pressure heads relative to atmospheric pressure applied with minimum disturbance on the same soil surface (Ankeny et al. 1991, Angulo-Jaramillo et al. 2016). A sequence of measurements with increasing water pressure head enables the role of macropores in water infiltration to be evaluated. The measured infiltration rates can be converted to hydraulic conductivity values using Wooding's theory of infiltration from a circular source (Wooding 1968).

Soil hydraulic conductivity is dynamic by nature, so the spatial and especially temporal variation in measured values may be one order of magnitude or even greater (Elrick and Reynolds 1992, Messing and Jarvis 1993, Hu et al. 2009, Bodner et al. 2013). Soil structure is the principal factor determining flow rates (Kutílek 2004, Bronick and Lal 2005, Alaoui et al. 2011). Total porosity and pore size are both important, as the largest pores are the most conductive in saturated state and the first to empty, thereby becoming barriers to water flow in unsaturated conditions, whereas small pores remain saturated and conductive (Angulo-Jaramillo et al. 2016). Texture is an intrinsic structure-determining property giving rise to different pore sizes in soil (Dexter 2004). In addition, soil organic matter content (Franzluebbers 2002) and any factor or activity that modifies structure, e.g., vegetation (Angers and Caron 1998), tillage (Lipiec et al. 2006, Horel et al. 2015, Pires et al. 2017), compaction due to field traffic (Ankeny et al. 1990, Sandin et al. 2017), changes in moisture causing shrinking, swelling, and slaking (Collis-George and Lal 1971, Lin et al. 1998, Peng et al. 2007), and changes in water repellency (DeBano 1981) influence soil hydraulic conductivity (Bodner et al. 2013, Jarvis et al. 2013). 
There is a global database of TI measurements conducted in field conditions collated by Jarvis et al. (2013). To our knowledge, however, TI measurements have rarely been applied in characterization of the hydraulic properties of arable soils in Finland. Applications to forest soils are also rare (Mecke and Ilvesniemi 1999, Mecke et al. 2000). The objectives of this study were thus to 1) provide reference values for near-saturated hydraulic conductivity $(K(h))$ in cultivated fine and coarse-textured mineral soils of Finland and 2 ) to quantify the variation in these values induced by different environmental or management factors. In the study, TI measurements were carried out in south-western and central-eastern Finland, on fields varying in texture, organic matter content, crop species, tillage, and antecedent moisture status. The intention was to provide novel information on near-saturated $\mathrm{K}(\mathrm{h})$ in the topsoils of Finland and to constitute a baseline for interpretation and comparison of future measurements, thus facilitating adoption of the technique in future studies. Appropriate data on near-saturated $\mathrm{K}(\mathrm{h}) \mathrm{can}$ also serve in refining pedotransfer functions and in hydrological modeling in general.

\section{Material and methods}

\section{Tension infiltrometer measurements}

Field measurements of near-saturated $\mathrm{K}(\mathrm{h})$ were carried out using four TI devices from Soil Measurement Systems LLC (Huntington Beach, CA, USA), which consist of a $0.2 \mathrm{~m}$ diameter porous disk connected to separate water reservoir and bubble towers. Selected infiltration sites were prepared by clipping all vegetation at soil level, after which the soil surface was gently levelled and smoothed with minimum disturbance to the soil surface. To ensure proper hydraulic connection between disk and soil, a thin layer of moist fine sand was applied under the disk, using a retaining ring. The water reservoir base was carefully levelled at the same height as the disk. In fields growing cereals, the disc covered randomly one or two plant rows due to the typical distance of $12.5 \mathrm{~cm}$ between drills. A supply pressure head of $-6,-3$ and $-1 \mathrm{~cm}$ was applied, in that sequence, at the infiltration surface, unless otherwise stated. At each pressure head, the water level in the reservoir tower was read manually at $15 \mathrm{~s}$ to 10 min intervals, depending on the water flow rate, until apparent steady-state infiltration was reached. The duration of the experiment varied from $5 \mathrm{~min}$ to $3 \mathrm{~h}$ such that longer measurement times were required in clay than in coarser soils. The measurement time also decreased with increasing supply pressure head. At low infiltration rates, the accuracy of measurement was improved by increasing the water level drop, by placing a solid plastic cylinder of $2 \mathrm{~cm}$ diameter inside the water reservoir. The water reservoir tower was refilled with tap water between supply pressure head increments.

The near-saturated $\mathrm{K}(\mathrm{h})$ at each pressure head was calculated from the measured successive steady-state infiltration rates, using the method detailed by Ankeny et al. (1991) and Reynolds and Elrick (1991). This method is based on Wooding's theory of unconfined infiltration from a circular source, which assumes homogeneous, isotropic, and uniformly unsaturated soil. The contribution of pores larger than $1 \mathrm{~mm}$ in diameter to field saturated hydraulic conductivity $\left(\mathrm{K}_{\mathrm{fs}}\right)$, i.e. macropore flow $(\%)$, was calculated as (Watson and Luxmoore 1986):

$$
\varphi_{M}=\frac{K_{f s}-K(-3)}{K_{f s}}
$$

The $\mathrm{K}_{\mathrm{fs}}$ values were obtained by extrapolating to zero supply pressure head (see e.g. Jarvis and Messing 1995) using Gardner's (1958) exponential hydraulic conductivity function.

\section{Field sites}

Data on soil near-saturated K(h) were collected between May and October in three consecutive years (20162018) at research stations of the Natural Resources Institute Finland (Luke) in Jokioinen in south-western Finland $\left(60^{\circ} 48^{\prime} \mathrm{N}, 23^{\circ} 28^{\prime} \mathrm{E}\right)$ and Maaninka in central-eastern Finland $\left(63^{\circ} 8^{\prime} \mathrm{N}, 27^{\circ} 18^{\prime} \mathrm{E}\right)$. The measurements were conducted on fine and coarser-textured cultivated soils under cereals (barley, oat, wheat) and perennial grasses (a mixture of timothy and meadow fescue) (Table S1) and also in set-aside fields established in 2003 with different seed mixtures (Hyvönen and Huusela-Veistola 2011). In Maaninka, the fields under cereal production are tilled conventionally, typically by ploughing to around $20 \mathrm{~cm}$ depth in autumn and harrowing and sowing cereals in spring, whereas in Jokioinen, reduced tillage is the common soil management practice. Leys are typically ploughed down and re-sown every four years, in a cereal cover crop. 
Agricultural soils in the Jokioinen region are dominated by fine-textured mineral soils typical for the south-western Finland, whereas coarser-textured mineral soils dominate in the Maaninka region (Lemola et al. 2018). At 0-20 $\mathrm{cm}$ depth, the soil type at the selected study sites ranged from clay to loamy sand, with a content of 0-78\% clay, $16-70 \%$ silt, and $3-71 \%$ fine sand (size classes $<2.0,2.0-60$, and $>60 \mu \mathrm{m}$, respectively) (Table S1). Organic carbon content in the $0-10 \mathrm{~cm}$ soil layer ranged from 2.0 to $8.3 \%$ and dry bulk density from 0.9 to $1.5 \mathrm{~g} \mathrm{~cm}^{-3}$. In Finland, the fine clay fraction generally consists of illite, chlorite, smectite, vermiculite, and amorphous material, while the content of feldspar and quartz increases with increasing particle size (Sippola 1974).

\section{Weather conditions}

Meteorological data on e.g. air temperature $\left({ }^{\circ} \mathrm{C}\right)$ and precipitation $(\mathrm{mm})$ were obtained from the Finnish Meteorological Institute's observation stations located at Jokioinen and Maaninka (Finnish Meteorological Institute 2019). Long-term averages for the normal meteorological period 1981-2010 were obtained from Pirinen et al. (2012).

During the study period 2016-2018, mean annual temperature exceeded the long-term average (Jokioinen $4.6^{\circ} \mathrm{C}$, Maaninka $3.2^{\circ} \mathrm{C}$ ) by $0.6-1.3^{\circ} \mathrm{C}$ (Fig. 1). The growing season lasted from late-April/mid-May to October, with effective temperature sum (degree days $>+5^{\circ} \mathrm{C}$ ) ranging from 1183 to $1725^{\circ} \mathrm{C}$ in Jokioinen and from 1073 to $1617^{\circ} \mathrm{C}$ in Maaninka.
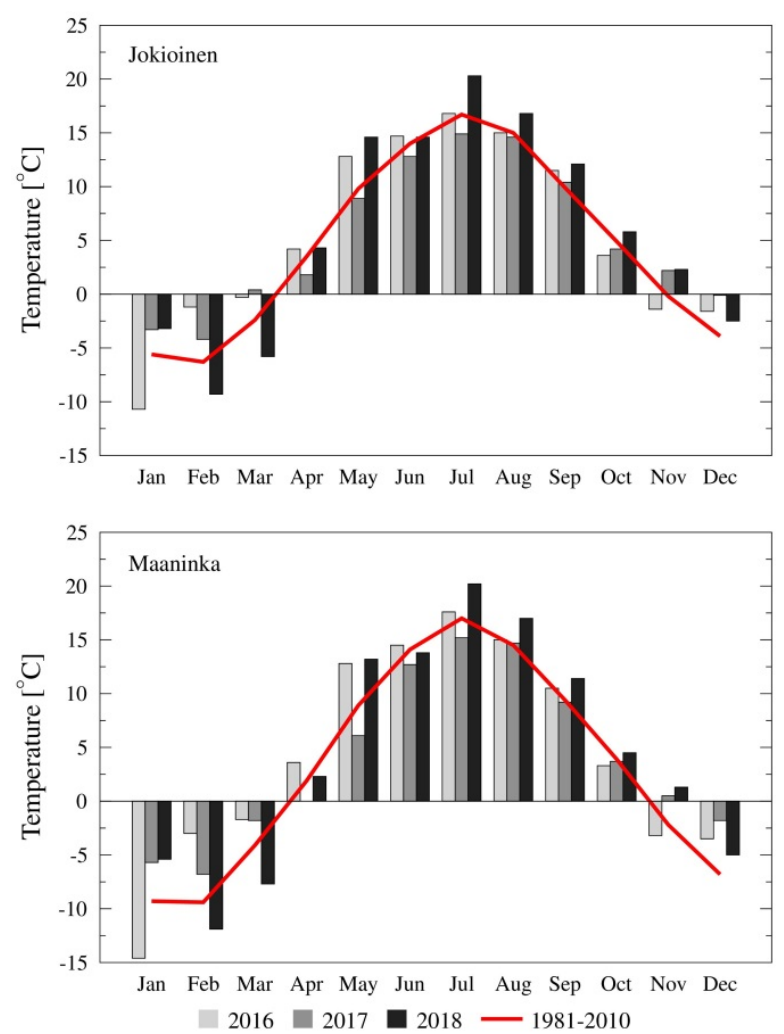

Fig. 1. Mean monthly temperature in the study period (2016-2018) and long-term average for the normal period (1981-2010) in Jokioinen and Maaninka

Mean annual precipitation in 2016, 2017, and 2018 was 536, 657, and $437 \mathrm{~mm}$, respectively, in Jokioinen and 544, 623, and $512 \mathrm{~mm}$, respectively, in Maaninka. In 2016 and 2018, annual precipitation was 15-30\% lower than the long-term average in Jokioinen and 11-16\% lower in Maaninka, whereas in 2017 it was slightly higher at both sites (Fig. 2). The growing season of 2017 was rainy and wet especially in Jokioinen, whereas the growing season of 2016 and 2018 was generally characterized by dryer conditions. 

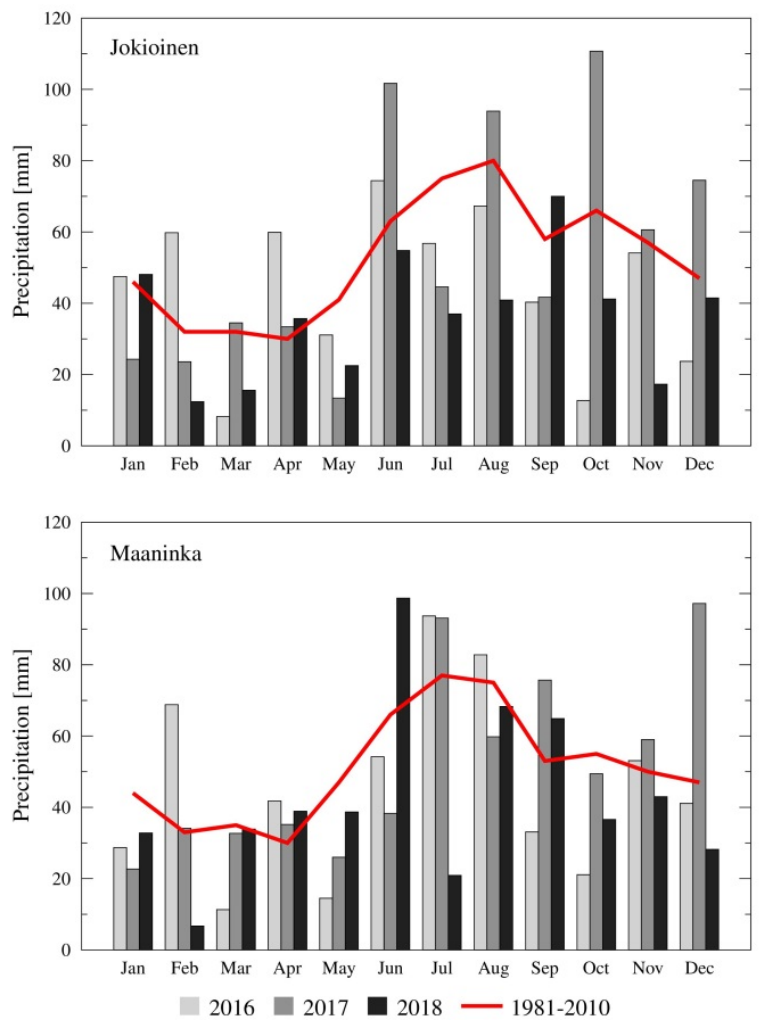

Fig. 2. Mean monthly precipitation in the study period (2016-2018) and long-term average for the normal period (1981-2010) in Jokioinen and Maaninka

\section{Data collection}

\section{General level of near-saturated K(h)}

Measurements of near-saturated K(h) were carried out in a total of 20 field plots, some of which were visited several times (see Table S1). The dataset was compiled to reveal the range of spatial and temporal variation between and within the fields at the experimental stations. To allow the influence of tillage systems, antecedent soil moisture content and earthworm burrows on the observed variation in near-saturated $K(h)$ to be estimated, specific set-ups described in detail below were included in the measurement scheme. Overall, the study comprised 60 measurement events covering 169-196 individual replicates at each of the pressure heads applied.

\section{Spatial variability in near-saturated $\mathrm{K}(\mathrm{h})$ within fields}

Spatial variability within each field plot was assessed by means of coefficient of variation (CV) calculated from measurements conducted either simultaneously or over a few successive days under similar conditions. In each field, at least three replicate measurement sites were established within a radius of $10 \mathrm{~m}$. The final dataset encompassed within-field CV for 44 measurement events.

\section{Effects of tillage systems on soil near-saturated K(h)}

The effect of tillage on near-saturated $\mathrm{K}(\mathrm{h})$ was examined in Kotkanoja leaching field at Jokioinen (Turtola et al. 2007). The soil at the field site is classified as a Protovertic Luvisol (Clayic, Cutanic) and its topsoil clay content ranges from 50 to $60 \%$ (Uusitalo et al. 2018). The measurements reported here were performed in summer 2017 and 2018 in a no-till plot (KO B) and a ploughed plot (KO C) (Table S1). Following a six-year period of grass ley, spring cereals have been grown in both plots since autumn 2008. Plot KO C is autumn-ploughed annually and harrowed in May for seedbed preparation. Full details of the management regime for the Kotkanoja field can be found in Uusitalo et al. (2018). Measurements were performed four times (with four replicates) in both 2017 and 2018 except in plot KO C, which was ploughed on the last measurement occasion in 2018. In both years, the first measurement was made after sowing in late May, followed by measurements in the second half of June, around mid-July, and after harvesting in September. The purpose of these measurements was to compare how contrasting tillage practices affect near-saturated $K(h)$ and its temporal variation. 


\section{Effects of antecedent soil moisture content on near-saturated $\mathrm{K}(\mathrm{h})$}

To assess the impact of antecedent soil moisture content on near-saturated $\mathrm{K}(\mathrm{h})$ values, sequential measurements were conducted at exactly the same spot on progressively wetter soil during three consecutive days. These measurements were carried out in four field plots (JII and KII at Jokioinen, Pohjoispelto 1 and 2 at Maaninka), with four replicate measurements in each at each wetting stage. For some missing replicates in Pohjoispelto 1 and 2, see Table S1. On the first day, the prevailing soil moisture regime was the starting point. After the measurements, the $\mathrm{TI}$ device was removed and the site $(0.75 \times 0.75 \mathrm{~m})$ was gently watered with an amount of tap water corresponding to $20 \mathrm{~mm}$ rainfall. On the second day, the fine sand layer constructed under the disk on the first day was carefully restored and the measurements were repeated. Thereafter, the site was watered as after the first measurements. On the third day, the measurement procedure was again repeated. Samples for gravimetric soil moisture content analysis were collected every day at 5-cm intervals to 0-20 cm depth within the watered area at approximately $30 \mathrm{~cm}$ distance from the edge of the TI disk, without disturbing the experiment. Gravimetric moisture content was converted to volumetric moisture content using dry bulk density values measured at each of the field plots. Finally, daily changes in near-saturated $\mathrm{K}(\mathrm{h})$ were related to changes in soil moisture content.

\section{Effects of earthworm burrows on near-saturated $\mathrm{K}(\mathrm{h})$}

The effect of soil structural changes caused by dew worm (Lumbricus terrestris) on near-saturated soil hydraulic properties was assessed in the Kotkanoja leaching field. Dew worms were originally absent from this field, but were introduced in 1996 at one end of the field (Nuutinen et al. 2006), from where the population is currently spreading (Nuutinen et al. 2011, Nuutinen et al. 2017). Our TI measurements were carried out close to the field edge where dew worms were first introduced. The measurements were performed at the top of four earthworm middens and at four adjacent control spots without middens. In this set-up, supply pressure head steps of $-4,-3$, -2 , and $-1 \mathrm{~cm}$ were used.

\section{Statistical analyses}

The general level and spatial variation in near-saturated $K(h)$ were described using the distribution of the data, including simple means, percentiles, and ranges. The effects of antecedent soil moisture content on near-saturated $\mathrm{K}(\mathrm{h})$ were assessed qualitatively, due to the limited number of observations.

Statistical analysis of tillage system was based on a repeated measures design with two field plots (KO B, KO C), two years $(2017,2018)$, four months (May, June, July, September), three supply pressure head values $(-6,-3,-1$ $\mathrm{cm})$, and four replicates. A linear mixed model (LMM) with log-transformed hydraulic conductivity was used, with field, year, month, supply pressure head, and all their interactions as fixed effects. Correlations between months and supply pressure head values were taken into account using an UN@AR(1) covariance structure, which specifies the Kronecker product of an unstructured covariance matrix of months and a first-order autoregressive covariance matrix of supply pressure head. The mean estimates in the log scale were back-transformed to the original scale corresponding to the medians on the original scale.

Statistical analysis of earthworm burrows was based on a repeated measures design with two treatments (control, dew worm), four supply pressure heads $(-4,-3,-2,-1 \mathrm{~cm})$, and four replicates. A generalized linear mixed model (GLMM) with gamma (with log link) distribution was used, with treatment, supply pressure head, and their interaction as fixed effects. Correlation between supply pressure head values was taken into account using a heterogeneous first-order autoregressive $(\mathrm{ARH}[1])$ covariance structure.

The suitability of the models was studied by residual analysis. LMM was fitted using the residual maximum likelihood (REML) and GLMM using the residual pseudo-likelihood (RSPL) estimation method. The degrees of freedom were calculated using the Kenward-Roger method. The method of Westfall was used for pairwise comparisons of means (Westfall 1997). A significance level of $\alpha=0.05$ was used in all analyses. The analyses were performed using the GLIMMIX procedure in SAS Enterprise Guide 7.15 (SAS Institute Inc., Cary, NC, USA). 


\section{Results and discussion}

The value of near-saturated $\mathrm{K}(\mathrm{h})$ determined in arable mineral topsoils of south-western and central-eastern Finland over the three-year study period ranged from 0.02 to $12.6 \mathrm{~mm} \mathrm{~h}^{-1}$ at $-6 \mathrm{~cm}$ pressure head, from 0.30 to 85.9 $\mathrm{mm} \mathrm{h}^{-1}$ at $-3 \mathrm{~cm}$ pressure head, and from 2.55 to $250 \mathrm{~mm} \mathrm{~h}^{-1}$ at $-1 \mathrm{~cm}$ pressure head (Table 1 ). Based on previously reported data for a clay soil in Sweden (Messing and Jarvis 1993), silt loam in Austria (Bodner et al. 2013), silty loam in Portugal (Cameira et al. 2003), sandy loam in China (Hu et al. 2009), and silt and sand soils in Pennsylvania U.S. (Zhou et al. 2008), the range of values obtained seems rather typical for mineral soils.

The distribution of near-saturated $\mathrm{K}(\mathrm{h}$ ) values in the clay and coarser-textured soils were largely overlapping (Table 1). However, at $-6 \mathrm{~cm}$ supply pressure head, the clay soils tended to show lower values than the coarser-structured soils, while at $-1 \mathrm{~cm}$ supply pressure head the order was reversed. This is in agreement with findings by Jarvis and Messing (1995) and Lin et al. (1997), who attributed the high near-saturated K(h) values of well-structured clay soils at near-zero pressure heads to the significant impact of continuous macropores (pore size $>0.5$ $\mathrm{mm}$ ). In coarse-textured soils, the pore size distribution is more uniform than in clays and thus water flows more evenly through various sizes of pores (Lin et al. 1997). Consequently, at supply pressure heads where macropores are not conductive, infiltration rates are greater in coarser- than finer-textured soils.

Table 1. Distribution of near-saturated hydraulic conductivity $(\mathrm{K}(\mathrm{h}))$ values measured in 20 field plots at the Jokioinen and Maaninka research stations, 2016-2018

\begin{tabular}{|c|c|c|c|c|c|c|c|c|}
\hline \multirow{2}{*}{$\begin{array}{l}\text { Supply pressure } \\
\text { head (h) }\end{array}$} & & \multicolumn{7}{|c|}{$\mathrm{K}(\mathrm{h})\left(\mathrm{mm} \mathrm{h}^{-1}\right)$} \\
\hline & & $\mathrm{n}$ & $\min$ & $\begin{array}{c}25 \text { th } \\
\text { percentile }\end{array}$ & med & $\begin{array}{c}\text { 75th } \\
\text { percentile }\end{array}$ & $\max$ & mean \\
\hline \multirow[t]{3}{*}{$-6 \mathrm{~cm}$} & Whole data & 164 & 0.02 & 0.46 & 0.78 & 2.97 & 12.6 & 1.92 \\
\hline & Clay soils & 121 & 0.02 & 0.37 & 0.67 & 1.28 & 10.0 & 1.37 \\
\hline & Coarser soils & 43 & 0.10 & 0.82 & 2.65 & 5.13 & 12.6 & 3.47 \\
\hline \multirow[t]{3}{*}{$-3 \mathrm{~cm}$} & Whole data & 198 & 0.30 & 1.41 & 3.42 & 9.74 & 85.9 & 7.15 \\
\hline & Clay soils & 155 & 0.30 & 1.22 & 2.79 & 9.87 & 85.9 & 7.31 \\
\hline & Coarser soils & 43 & 0.42 & 2.16 & 5.39 & 9.63 & 22.9 & 6.54 \\
\hline \multirow[t]{3}{*}{$-1 \mathrm{~cm}$} & Whole data & 196 & 2.55 & 15.6 & 30.2 & 61.3 & 250 & 46.5 \\
\hline & Clay soils & 153 & 3.28 & 17.4 & 38.1 & 72.1 & 250 & 54.1 \\
\hline & Coarser soils & 43 & 2.55 & 11.2 & 17.0 & 22.8 & 72.0 & 19.4 \\
\hline
\end{tabular}

Although macropores occupy only a minor proportion of the soil total porosity, they make a major contribution to low-tension water flow (Jarvis 2007, Lin et al. 1997). In the present study, on average $94 \pm 7 \%$ and $74 \pm 20 \%$ of the estimated water flow at $\mathrm{K}_{\mathrm{fs}}$ was transmitted through macropores (pore diameter $>1 \mathrm{~mm}$ ) in the clay and coarser-textured soils, respectively. In the study by Lin et al. (1997), the mean contribution of macropores (>0.75 $\mathrm{mm}$ ) to total water flow was $78 \%$ in clays and $49 \%$ in sands. High contributions of macropores (>0.5 mm) to water flow have also been reported by Azevedo et al. (1998) and Cameira et al. (2003), whereas in the sandy loam soils investigated by Hu et al. (2009) the contribution remained below $20 \%$.

Hydraulic conductivity is considered to be among the most highly variable inherent soil physical properties, with CV typically exceeding 100\% (Warrick and Nielsen 1980). Consequently, the within-field CV values obtained in the present study, ranging between 2 and 141\%, can be taken to reflect only moderate spatial heterogeneity (Fig. 3). This probably results from the rather small area explored in each field and from the use of adequate disk size in relation to the spatial variation. Advances in equipment for in situ near-saturated $\mathrm{K}(\mathrm{h})$ measurements likely contributed to the moderate degree of variation, by reducing the error in flow rate determination. The CV values in our study are similar to those observed in field conditions by Jarvis and Messing (1995), Shouse and Mohanty (1998), Cameira et al. (2003), and Hu et al. (2009). In the present study, the within-field variation tended to increase with increasing supply pressure head, as also reported by Das Gupta et al. (2006), Hu et al. (2009), Schwen et al. (2011), and Bodner et al. (2013). This can be attributed to variations in the presence of macropores. 


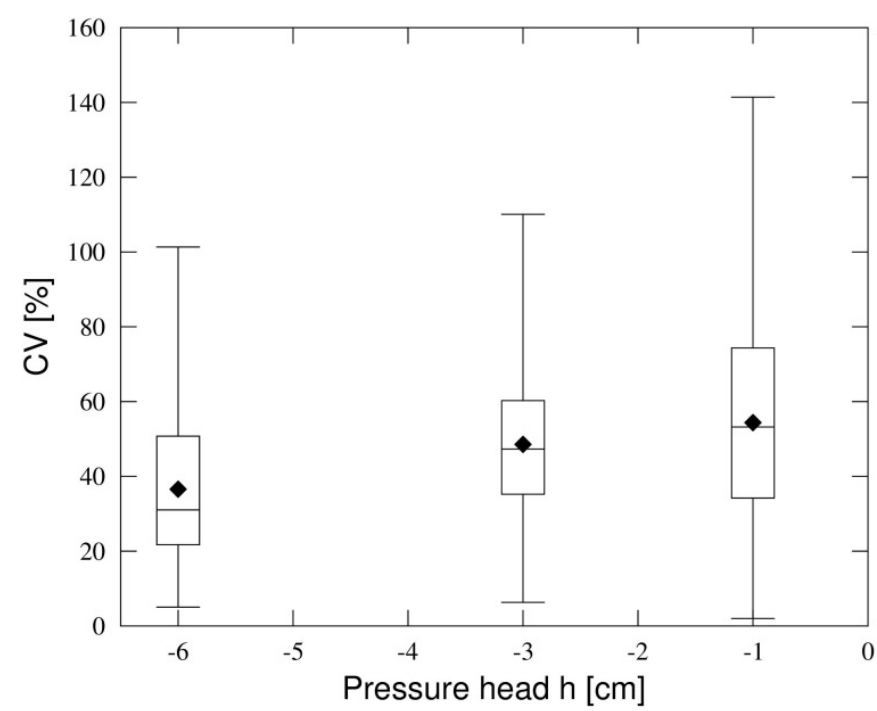

Fig. 3. Distributions of coefficient of variation (CV, \%) in near-saturated hydraulic conductivity $(\mathrm{K}(\mathrm{h}))$ measured within a field plot either simultaneously or over a few successive days of similar conditions. Arithmetic means are indicated by diamonds, whereas the boxes denote medians and lower and upper quartiles, and the whiskers minimum and maximum values. $\mathrm{n}=38$ for pressure head $(\mathrm{h})=$ $-6 \mathrm{~cm}, \mathrm{n}=44$ for $\mathrm{h}=-3$ and $-1 \mathrm{~cm}$

Several previous studies have shown the variation in near-saturated $K(h)$ to be higher in time than in space (e.g. Messing and Jarvis 1993, Zhou et al. 2008, Hu et al. 2009, Bodner et al. 2013). In the present study, temporal variation in near-saturated $\mathrm{K}(\mathrm{h})$ was observed together with the effects of tillage in the Kotkanoja leaching field (Fig. 4). While weather conditions differed quite markedly between the two measurement years $(2017,2018)$, there were no statistically significant differences between the corresponding measurements in 2017 and 2018, with the exception of supply pressure head $-1 \mathrm{~cm}$ in the no-till plot in late May. Similar trends in near-saturated $\mathrm{K}(\mathrm{h})$ were observed in both years. In the ploughed plot $(\mathrm{KO} C), \mathrm{K}(\mathrm{h}$ ) declined by roughly one order of magnitude during the growing season at all supply pressure heads applied and the results showed a clear decreasing trend. In almost all cases, the near-saturated $\mathrm{K}(\mathrm{h}$ ) values obtained on the first measurement occasions (May) differed significantly from those on the last occasions (September 2017 or July 2018), the only exception being for supply pressure head -1 $\mathrm{cm}$ in 2018. In the no-till plot (KO B), near-saturated $\mathrm{K}(\mathrm{h}$ ) did not show a similar decreasing trend, but the values were lower at all pressure heads applied. At all pressure heads, differences between the ploughed and untilled soil were greatest in spring, after seedbed preparation. Due to post-tillage development of soil structure, after the measurements in May the differences between KO B and KO C plots decreased and were statistically significant on only a few occasions (pressure head $-3 \mathrm{~cm}$ in June 2018, pressure head -3 and $-6 \mathrm{~cm}$ in September 2017).

Strudley et al. (2008) reviewed the literature on tillage effects on hydraulic conductivity and concluded that published findings on the influence of no-till are inconsistent. They also concluded that the effects of tillage on soil hydraulic properties are greatest immediately after tillage, but diminish rapidly. Our results showed a similar trend.

The change in near-saturated $\mathrm{K}(\mathrm{h})$ over time during the growing season was different for soils under contrasting tillage practices, i.e. the soil structure developed differently after sowing. In previous research, it has generally been noted that recently tilled soils exhibit rapid near-saturated infiltration, before the soil structure is settled by rainfall events (Logston et al. 1993, Miller et al. 1998). Temporal variations in near-saturated K(h) during the growing season in Sweden have been reported by Messing and Jarvis (1993) and Sandin et al. (2017). Messing and Jarvis performed their measurements in a long-term (16-year-old) tillage experiment with clay soil (clay content $40 \%$ ). They observed a one order of magnitude decrease in near-saturated $K(h)$ at the soil surface and attributed this to soil structure breakdown, soil surface sealing, and compaction and mobilization of fine particles caused by raindrop impacts. Sandin et al. (2017) also observed a one order of magnitude decrease in near-saturated K(h) after sowing and, based on X-ray tomographic imaging of the soil structure, they attributed this to decreasing porosity during the growing season.

Many soil water transport models are based on assumption that soil surface characteristics are not time-dependent. In reality, however, hydraulic properties at the soil surface undergo temporal changes during the growing season 
as tillage and weather conditions modify the soil structure. Hu et al. (2009) reviewed studies conducted under various conditions and found that significant temporal changes in hydraulic properties were reported in most studies. Our results suggest that these changes are more drastic for intensively cultivated soil than for untilled soil.

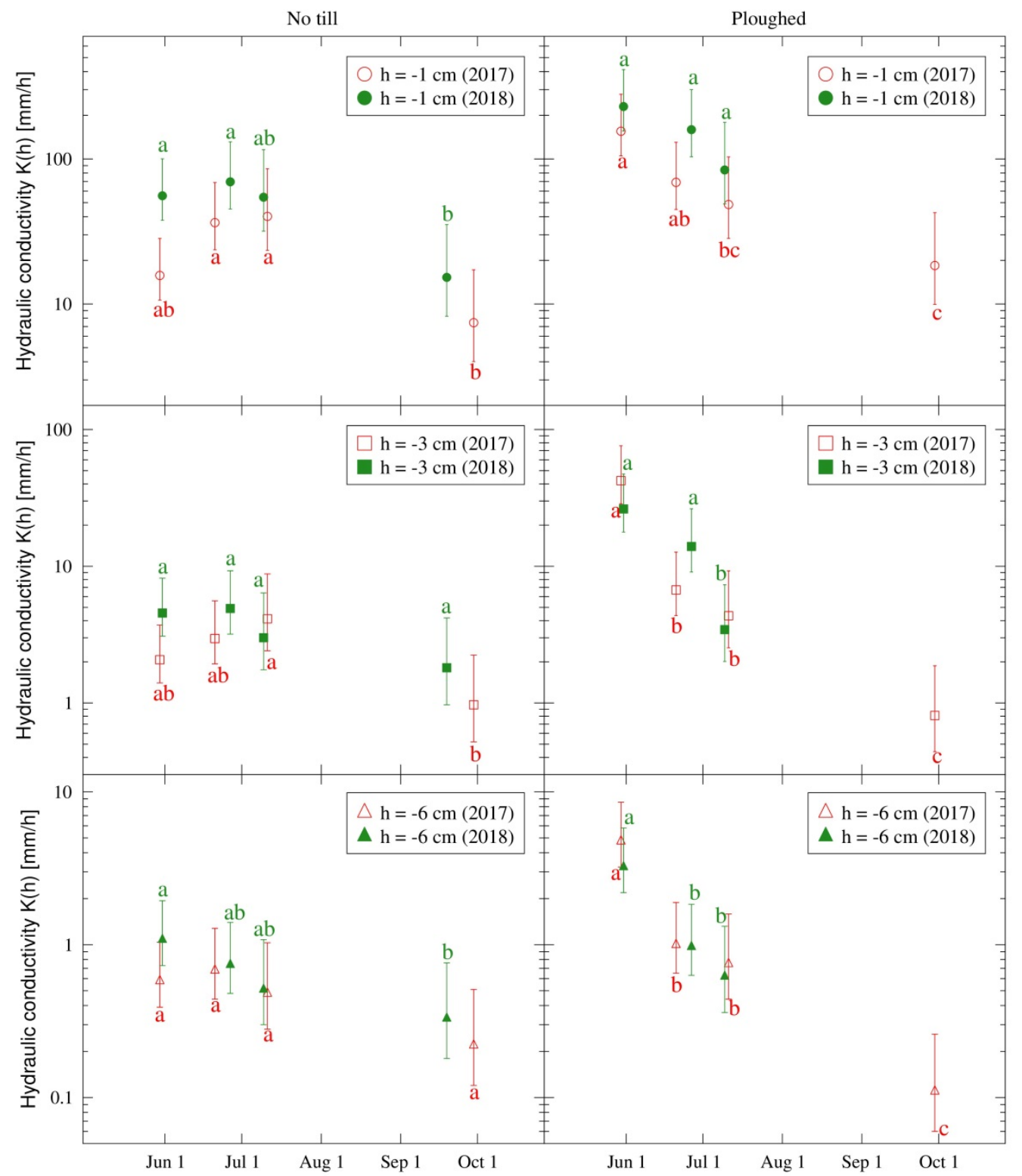

Fig. 4. Median estimates of near-saturated hydraulic conductivity $(K(h))$ measured using different supply pressure head (h; $-1,-3,-6 \mathrm{~cm}$ ) in (left) no-till and (right) autumn-ploughed plots in Kotkanoja leaching field, 2017-2018. Error bars denote $95 \%$ confidence interval. Different letters $(a, b, c)$ indicate statistically significant differences between sampling sites (within pressure head and year).

While it has been claimed that macroporosity and tillage do not follow a trend, but vary with weather conditions and cultivation practices (Logston et al. 1993), our results for the two subsequent years followed a very similar pattern, despite the contrasting weather conditions. The results for the no-till plot, which had been under reduced tillage since 1996 and no-till since 2002 (Uusitalo et al. 2018), suggest that the temporal changes in soil structure in this field differ markedly from those in the annually ploughed field. On the other hand, the structure of tilled soil appeared to settle, so that the differences in near-saturated $\mathrm{K}(\mathrm{h})$ vanished in less than one month. While there are no tillage operations to create new topsoil porosity in the no-till soil, other processes such as biological activity, wetting-drying cycles, and root growth in spring may induce development of pore structure during the growing season. However, the temporal variation in near-saturated $K(h)$ in no-till soil was clearly smaller than that in conventionally tilled soil. 
R. Keskinen et al. (2019) 28: 70-83

The substudy on the impacts of antecedent soil moisture content on near-saturated $\mathrm{K}(\mathrm{h})$ was started on relatively dry topsoil (Fig. 5). The first watering of $20 \mathrm{~mm}$ was apparently sufficient to bring the soils close to field capacity, as the second watering increased the volumetric soil moisture content only slightly, if at all.

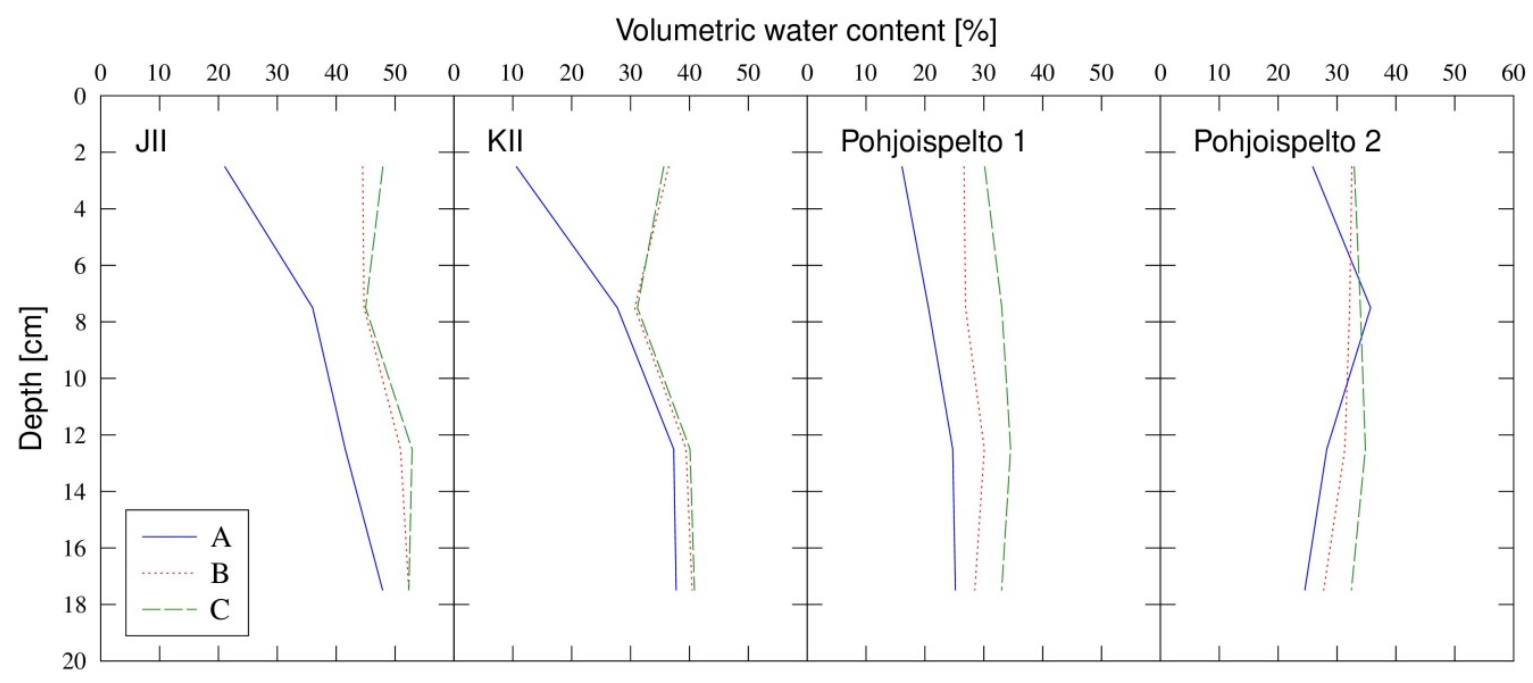

Fig. 5. Volumetric soil moisture content to $20 \mathrm{~cm}$ depth in fine-textured (JII, KII) and coarser-textured (Pohjoispelto 1 \& 2) plots used for assessing the impacts of antecedent soil moisture on near-saturated hydraulic conductivity $(\mathrm{K}(\mathrm{h}))$. A $=$ initial moisture status, $\mathrm{B}$ and $\mathrm{C}=$ moisture status after the first and second application of $20 \mathrm{~mm}$ water, respectively.

In clay soils, the increase in the antecedent soil moisture between the first two measurement events clearly increased the infiltration rate (Fig. 6.). This increase was most apparent at -6 and $-3 \mathrm{~cm}$ pressure head, but a similar trend could be seen with $-1 \mathrm{~cm}$. In coarser-textured soils, in contrast, the antecedent soil moisture conditions had no effect on the hydraulic conductivity at -6 and $-3 \mathrm{~cm}$ pressure head, while at $-1 \mathrm{~cm}$ the hydraulic conductivity rather tended to decrease as the antecedent soil moisture content increased. Previous studies on the effects of antecedent soil moisture content on water infiltration close to saturation also report contrasting effects (Everts and Kanwar 1993, Lin et al. 1998, Das Kupta et al. 2006, Zhou et al. 2008). For example, Everts and Kanwar (1993), Lin et al. (1998), and Zhou et al. (2008) observed a negative relationship between antecedent soil moisture content and near-saturated water flow due to wetting-induced decrease in soil macroporosity. However, Das Kupta et al. (2006) found that near-saturated K(h) values were positively correlated with antecedent moisture conditions, which they attributed to increased conductivity in structural cracks and macropores due to increase in bridges of water films.

In structurally unstable soils, blocking of macropores may occur due to collapse of aggregates upon wetting (CollisGeorge and Lal 1971, Le Bissonnais 1996). This effect may explain the decreasing trend in near-saturated K(h) observed at $-1 \mathrm{~cm}$ pressure head in the coarser soils of Maaninka that are low in clay. This assumption is supported by a clear decrease in the relative contribution of macropores to total water flow at estimated $\mathrm{K}_{\mathrm{fs}}$ as the soil antecedent moisture content increased (Fig. 6). In the clay soils of Jokioinen, the relative contribution of macropores to total water flow likewise decreased with increasing antecedent moisture content, but to a lesser degree than in the coarser-structured soils. Shrinking and swelling of expansive clay soils due to drying and wetting is known to cause opening and closing of cracks (Lin et al. 1998), but with the short duration of the present experiment and the rather high stability of the clays involved, it is unlikely that notable loss in macroporosity occurred in these soils. The clear increase observed in flow rates with increasing antecedent soil moisture content was likely caused by enhanced film flow along the walls of large air-filled macropores and increased matrix flow (Bouma and Dekker 1978). In dry conditions, infiltration can be governed by preferential flow due to restricted lateral movement of water caused by water repellency of the soil (Bouma and Dekker 1978, Ritsema and Dekker 2000, Jarvis 2007). The effect of water repellency on near-saturated $K(h)$ has been studied in detail by Jarvis et al. (2008). 

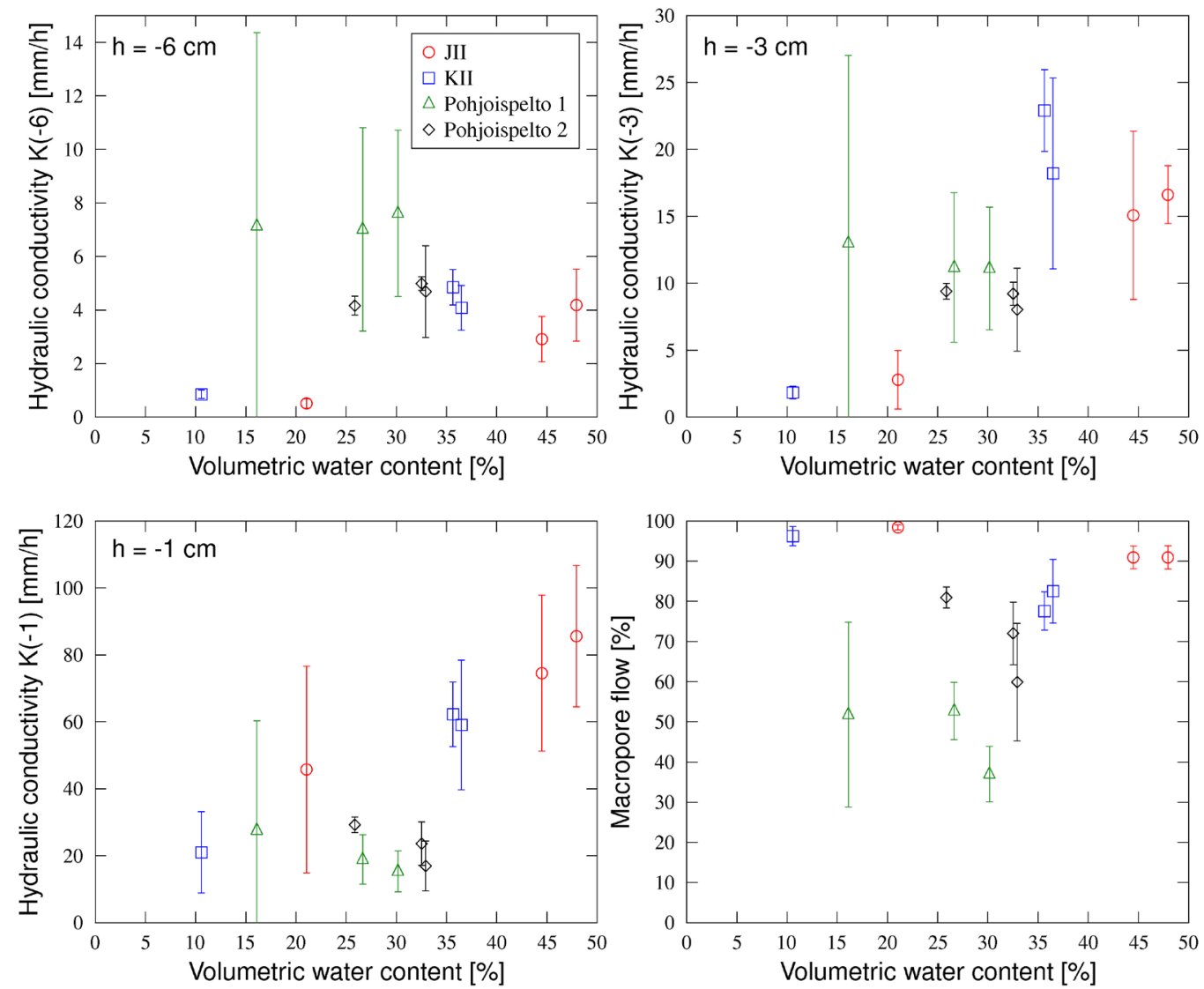

Fig. 6. Near-saturated hydraulic conductivity $(\mathrm{K}(\mathrm{h})$ ) in fine-textured (JII and $\mathrm{KII}$ ) and coarser-textured (Pohjoispelto 1 and 2) plots at different supply pressure heads $(\mathrm{h} ;-6,-3,-1 \mathrm{~cm})$ with progressively wetter antecedent soil moisture conditions and estimated proportion of macropore flow. The values are averages of four replicate measurements \pm standard deviation.

Earthworm burrows form macropores, the effects of which on soil near-saturated $\mathrm{K}(\mathrm{h})$ were observed in the no-till plot in Kotkanoja leaching field. The supply pressure head used was $-4,-3,-2$, and $-1 \mathrm{~cm}$, which according to capillary theory excludes pores of equivalent pore diameter greater than $0.7,1.0,1.5$, and $2.9 \mathrm{~mm}$, respectively, from the infiltration process. No statistically significant differences were observed for the three lowest supply pressure heads (Fig. 7).

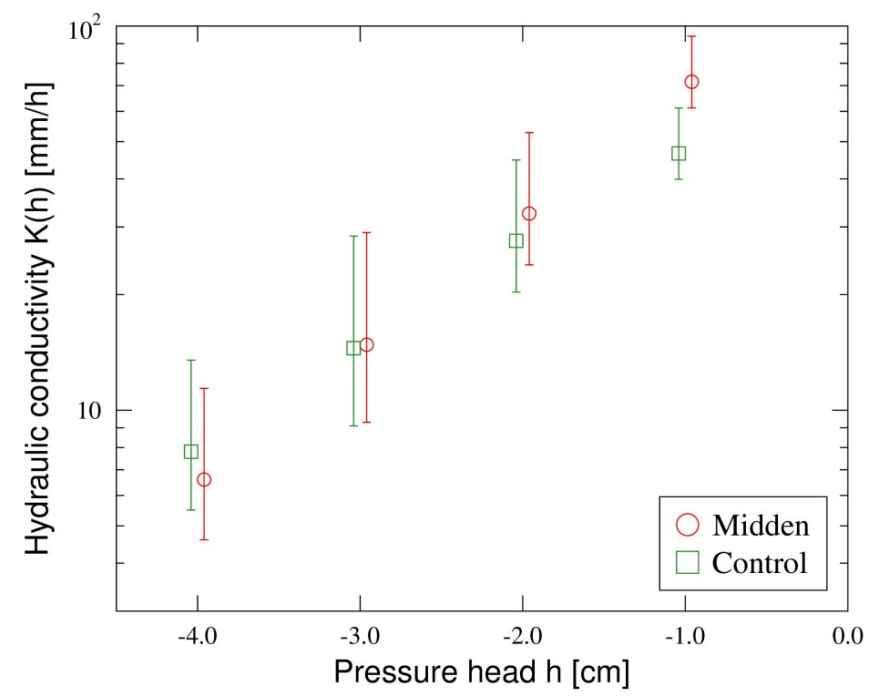

Fig. 7. Mean estimates of near-saturated hydraulic conductivity $(\mathrm{K}(\mathrm{h}))$ measured at earthworm midden and non-midden sites. Error bars denote $95 \%$ confidence interval, differences only significant for pressure head $(h)=$ $-1 \mathrm{~cm}$. For clarity, overlapping data points are displaced horizontally. 
However, for the pressure head of $-1 \mathrm{~cm}$, hydraulic conductivity at midden locations was 1.5-fold higher than at non-midden sites. There are several possible explanations for this. Burrows are known to act as biological hotspots supporting elevated faunal abundances (e.g. Stroud et al. 2016) and it is possible that the elevated faunal activity in the surroundings of dew worm burrows increased soil porosity in the millimetre size range. Another explanation relates to fluctuations in the supply pressure head during measurements around the nominal pressure, due to bubbling (Ankeny et al. 1988). These fluctuations may temporarily allow flow in dew worm burrows. Moreover, earthworm burrows are not perfectly cylindrical capillaries, so they can increasingly contribute to infiltration on becoming wetter without being fully saturated (Tuller et al. 1999, Tuller and Or 2002). Thus film and pulse flow (Tofteng et al. 2002) along burrow walls may contribute to observed differences at high supply pressure head. Jarvis et al. (1987) used dye tracing together with $\mathrm{Tl}$ and observed that earthworm channels with diameter ranging from 1 to $4 \mathrm{~mm}$ were stained only at a pressure head of $-0.5 \mathrm{~cm}$ but not $-2 \mathrm{~cm}$. Cey and Rudolph (2009) also used dye tracers to investigate macropore flow and found that at a pressure head of $-0.4 \mathrm{~cm}$, thin film flow occurred in earthworm burrows. These observations suggest that film flow along earthworm burrow walls is a plausible explanation for the difference we observed at a pressure head of $-1 \mathrm{~cm}$. In any case, our results show that earthworm burrows may influence the results of TI measurements at high supply pressure heads and that a 20-cm diameter disk is not able to average out this effect. Nuutinen et al. (2017) recently determined the density of earthworm middens at Kotkanoja and found that it was approximately 20 middens $\mathrm{m}^{-2}$ close to our measurement site. This density corresponds to approximately 0.6 middens per disk area, making it quite arbitrary whether a randomly selected measurement site would be located above a midden or not. Thus, if TI measurements are performed at a field populated by earthworms, part of the observed variation in $\mathrm{K}(\mathrm{h})$ may result from earthworm burrows.

\section{Conclusions}

In situ measurements of near-saturated soil hydraulic conductivity $(K(h))$ using the $\mathrm{TI}$ technique were performed on fine- and coarser-textured arable topsoils in south-western and central-eastern Finland in three consecutive years. The range of values obtained at the soil surface was $0.02-12.6 \mathrm{~mm} \mathrm{~h}^{-1}$ at $-6 \mathrm{~cm}$ supply pressure head, $0.30-85.9$ $\mathrm{mm} \mathrm{h}^{-1}$ at $-3 \mathrm{~cm}$, and $2.55-250 \mathrm{~mm} \mathrm{~h}^{-1}$ at $-1 \mathrm{~cm}$. At $-6 \mathrm{~cm}$ pressure head, clay soils tended to show lower values than coarser-structured soils, but the order was reversed at $-1 \mathrm{~cm}$. Spatial variability in near-saturated $\mathrm{K}(\mathrm{h})$ was found to be moderate (CV 2-141\%, mean 56\%). Presence of earthworm burrows increased flow rates at higher supply pressure heads, i.e. at $-1 \mathrm{~cm}$, but temporal variations arising from post-tillage development of soil structure and variations in antecedent soil moisture status exceeded the spatial variation.

Use of the TI technique in this study provided novel information on near-saturated $K(h)$ in the arable mineral soils of Finland. This information can act as a baseline for interpretation and comparison of future measurements and serve in refining pedotransfer functions and in hydrological modeling in general. We suggest that in situ soil hydraulic characterization based on TI measurements be included among the physical indicators in soil quality assessment.

\section{Acknowledgements}

We wish to thank Dr Visa Nuutinen for guidance in identifying the earthworm middens. For funding of this study, we are grateful to Marjatta ja Eino Kollin säätiö.

\section{References}

Adhikari, K. \& Hartemink, A.E. 2016. Linking soils to ecosystem services - A global review. Geoderma 262: 101-111. https://doi. org/10.1016/j.geoderma.2015.08.009

Alaoui, A., Lipiec, J. \& Gerke, H.H. 2011. A review of the changes in the soil pore system due to soil deformation: A hydrodynamic perspective. Soil \& Tillage Research 115-116: 1-15. https://doi.org/10.1016/j.still.2011.06.002

Angers, D.A. \& Caron, J. 1998. Plant-induced changes in soil structure: Processes and feedbacks. Biogeochemistry 42: 55-72. https://doi.org/10.1007/978-94-017-2691-7_3

Angulo-Jaramillo, R., Bagarello, V., lovino, M. \& Lassabatere, L. 2016. Infiltration measurements for soil hydraulic characterization. Springer International Publishing, Switzerland. 386 p. https://doi.org/10.1007/978-3-319-31788-5

Angulo-Jaramillo, R., Vandervaere, J.-P., Roulier, S., Thony, J.-L., Gaudet, J.-P. \& Vauclin, M. 2000. Field measurement of soil surface hydraulic properties by disc and ring infiltrometers - A review and recent developments. Soil \& Tillage Research 55: 1-29. https:// doi.org/10.1016/S0167-1987(00)00098-2

Ankeny, M.D., Ahmed, M., Kaspar, T.C. \& Horton, R. 1991. Simple field method for determining unsaturated hydraulic conductivity. Soil Science Society of America Journal 55: 467-470. https://doi.org/10.2136/sssaj1991.03615995005500020028x 
R. Keskinen et al. (2019) 28: 70-83

Ankeny, M.D., Kaspar, T.C. \& Horton, R. 1988. Design for an automated tension infiltrometer. Soil Science Society of America Journal 52: 893-896. https://doi.org/10.2136/sssaj1988.03615995005200030054x

Ankeny, M.D., Kaspar, T.C. \& Horton, R. 1990. Characterization of tillage and traffic effects on unconfined infiltration measurements. Soil Science Society of America Journal 54: 837-840. https://doi.org/10.2136/sssaj1990.03615995005400030037x

Arshad, M.A. \& Martin, S. 2002. Identifying critical limits for soil quality indicators in agro-ecosystems. Agriculture, Ecosystems and Environment 88: 135-160. https://doi.org/10.1016/S0167-8809(01)00252-3

Azevedo, A.S., Kanwar, R.S.\& Horton, R. 1998. Effect of cultivation on hydraulic properties of an lowa soil using tension infiltrometers. Soil Science 163:22-29. https://doi.org/10.1097/00010694-199801000-00004

Beven, K. \& Germann, P. 2013. Macropores and water flow in soils revisited. Water Resources Research 49: 3071-3092. https:// doi.org/10.1002/wrcr.20156

Bodner, G., Scholl, P., Loiskandl, W. \& Kaul, H.-P. 2013. Environmental and management influences on temporal variability of near saturated soil hydraulic properties. Geoderma 204-205: 120-129. https://doi.org/10.1016/j.geoderma.2013.04.015

Bouma, J. \& Dekker, L.W. 1978. A case study on infiltration into dry clay soil I. Morphological observations. Geoderma 20: 27-40. https://doi.org/10.1016/0016-7061(78)90047-2

Bronick, C.J. \& Lal, R. 2005. Soil structure and management: a review. Geoderma 124: 3-22. https://doi.org/10.1016/j.geoderma.2004.03.005

Bünemann, E.K., Bongiorno, G., Bai, Z., Creamer, R.E., De Deyn, G., de Goede, R., Fleskens, L., Geissen, V., Kuyper, T.W., Mäder, P., Pulleman, M., Sukkel, W., van Groenigen, J.W. \& Brussaard, L. 2018. Soil quality - A critical review. Soil Biology and Biochemistry 120: 105-125. https://doi.org/10.1016/j.soilbio.2018.01.030

Cameira, M.R., Fernando, R.M. \& Pereira, L.S. 2003. Soil macropore dynamics affected by tillage and irrigation for a silty loam alluvial soil in southern Portugal. Soil \& Tillage Research 70: 131-140. https://doi.org/10.1016/S0167-1987(02)00154-X

Cey, E.E. \& Rudolph, D.L. 2009. Field study of macropore flow processes using tension infiltration of a dye tracer in partially saturated soils. Hydrological Processes 23: 1768-1779. https://doi.org/10.1002/hyp.7302

Collis-George, N. \& Lal, R. 1971. Infiltration and structural changes as influenced by initial moisture content. Australian Journal of Soil Research 9: 107-116. https://doi.org/10.1071/SR9710107

Das Gupta, S., Mohanty, B.P. \& Köhne, J.M. 2006. Soil hydraulic conductivities and their spatial and temporal variations in a Vertisol. Soil Science Society of America Journal 70: 1872-1881. https://doi.org/10.2136/sssaj2006.0201

DeBano, L.F. 1981. Water repellent soils: a state-of-the-art. Pacific Southwest Forest and Range Experiment Station General Technical Report PSW-46. Pacific Southwest Forest and Range Experiment Station, Berkeley, California. 25 p.

Dexter, A.R. 2004. Soil physical quality Part I. Theory, effects of soil texture, density, and organic matter, and effects on root growth. Geoderma 120: 201-214. https://doi.org/10.1016/j.geoderma.2003.09.004

Elonen, P. 1971. Particle-size analysis of soil. Acta Agralia Fennica 122: 1-122.

Elrick, D.E. \& Reynolds, W.D. 1992. Methods for analyzing constant-head well permeameter data. Soil Science Society of America Journal 56: 320-323. https://doi.org/10.2136/sssaj1992.03615995005600010052x

Everts, C.J. \& Kanwar, R.S. 1993. Interpreting tension-infiltrometer data for quantifying soil macropores: some practical considerations. Transactions of the American Society of Agricultural Engineers 36: 423-428. https://doi.org/10.13031/2013.28354

Finnish Meteorological Institute 2019. The Finnish Meteorological Institute's open data. Cited 2 January 2019. https:// en.ilmatieteenlaitos.fi/open-data. Creative Commons Attribution 4.0 International Public License. https://creativecommons.org/ licenses/by/4.0/legalcode.

Franzluebbers, A.J. 2002. Water infiltration and soil structure related to organic matter and its stratification with depth. Soil \& Tillage Research 66: 197-205. https://doi.org/10.1016/S0167-1987(02)00027-2

Gardner, W.R. 1958. Some steady-state solutions of the unsaturated moisture flow equation with application to evaporation from a water table. Soil Science 85: 228-232. https://doi.org/10.1097/00010694-195804000-00006

Gray, D.M. \& Norum, D.I. 1967. The effect of soil moisture on infiltration as related to runoff and recharge. In: National Research Council of Canada. Subcommittee of Hydrology. Soil Moisture. Proceedings of Hydrology Symposium No. 6. University of Saskatchewan, 15-16 November 1967. p. 133-153.

Horel, Á., Tóth, E., Gelybó, G., Kása, I., Bakacsi, Z. \& Farkas, C. 2015. Effects of Land Use and Management on Soil Hydraulic Properties. Open Geosciences 1:742-754. https://doi.org/10.1515/geo-2015-0053

Hu, W., Shao, M., Wang, Q., Fan, J. \& Horton, R. 2009. Temporal changes of soil hydraulic properties under different land uses. Geoderma 149: 355-366. https://doi.org/10.1016/j.geoderma.2008.12.016

Hyvönen, T. \& Huusela-Veistola, E. 2011. Impact of seed mixture and mowing on food abundance for farmland birds in set-asides. Agriculture, Ecosystems and Environment 143: 20-27. https://doi.org/10.1016/j.agee.2011.04.008

Jarvis, N.J. 2007. A review of non-equilibrium water flow and solute transport in soil macropores: principles, controlling factors and consequences for water quality. European Journal of Soil Science 58: 523-546. https://doi.org/10.1111/j.1365-2389.2007.00915.x

Jarvis, N., Etana, A. \& Stagnitti, F. 2008. Water repellency, near-saturated infiltration and preferential solute transport in a macroporous clay soil. Geoderma 143: 223-230. https://doi.org/10.1016/j.geoderma.2007.11.015

Jarvis, N., Koestel, J., Messing, I., Moeys, J. \& Lindahl, A. 2013. Influence of soil, land use and climatic factors on the hydraulic conductivity of soil. Hydrology and Earth System Sciences 17: 5185-5195. https://doi.org/10.5194/hess-17-5185-2013

Jarvis, N.J., Leeds-Harrison, P.B. \& Dosser, J.M. 1987. The use of tension infiltrometers to assess routes and rates of infiltration in a clay soil. Journal of Soil Science 38: 633-640. https://doi.org/10.1111/j.1365-2389.1987.tb02160.x 
R. Keskinen et al. (2019) 28: 70-83

Jarvis, N.J. \& Messing, I. 1995. Near-saturated hydraulic conductivity in soils of contrasting texture measured by tension infiltrometers. Soil Science Society of America Journal 59: 27-34. https://doi.org/10.2136/sssaj1995.03615995005900010004x

Kutílek, M. 2004. Soil hydraulic properties as related to soil structure. Soil \& Tillage Research 79: 175-184. https://doi.org/10.1016/j. still.2004.07.006

Le Bissonnais, Y. 1996. Aggregate stability and assessment of soil crustability and erodibility: I. Theory and methodology. European Journal of Soil Science 47: 425-437. https://doi.org/10.1111/j.1365-2389.1996.tb01843.x

Lemola, R., Uusitalo, R., Hyväluoma, J., Sarvi, M. \& Turtola, E. 2018. Suomen peltojen maalajit, multavuus ja fosforipitoisuus. Vuodet 1996-2000 ja 2005-2009. Luonnonvara- ja biotalouden tutkimus 17/2018. 209 p. (in Finnish).

Lin, H.S., McInnes, K.J., Wilding, L.P. \& Hallmark, C.T. 1997. Low tension water flow in structured soils. Canadian Journal of Soil Science 77: 649-654. https://doi.org/10.4141/S96-061

Lin, H.S., Mclnnes, K.J., Wilding, L.P. \& Hallmark, C.T. 1998. Macroporosity and initial moisture effects on infiltration rates in Vertisols and Vertic intergrades. Soil Science 163: 2-8. https://doi.org/10.1097/00010694-199801000-00002

Lipiec, J., Kuś, J., Słowińska-Jurkiewicz, A. \& Nosalewicz, A. 2006. Soil porosity and water infiltration as influenced by tillage methods. Soil \& Tillage Research 89: 210-220. https://doi.org/10.1016/j.still.2005.07.012

Logston, S.D., Jordahl, J.L. \& Karlen, D.L. 1993. Tillage and crop effects on ponded and tension infiltration rates. Soil \& Tillage Research 28: 179-189. https://doi.org/10.1016/0167-1987(93)90025-K

Mecke, M. \& Ilvesniemi, H. 1999. Near-saturated hydraulic conductivity and water retention in coarse podzol profiles. Scandinavian Journal of Forest Research 14: 391-401. https://doi.org/10.1080/02827589950154096

Mecke, M., Westman, C.J. \& Ilvesniemi, H. 2000. Prediction of near-saturated hydraulic conductivity in three podzolic boreal forest soils. Soil Science Society of America Journal 64: 485-492. https://doi.org/10.2136/sssaj2000.642485x

Messing, I. \& Jarvis, N.J. 1993. Temporal variation in the hydraulic conductivity of a tilled clay soil as measured by tension infiltrometers. Journal of Soil Science 44: 11-24. https://doi.org/10.1111/j.1365-2389.1993.tb00430.x

Miller, J.J., Sweetland, N.J., Larney, F.J. \& Volkmar, K.M. 1998. Unsaturated hydraulic conductivity of conventional and conservation tillage soils in southern Alberta. Canadian Journal of Soil Science 78: 643-648. https://doi.org/10.4141/S97-061

Nielsen, D.R., van Genuchten, M.Th. \& Biggar, J.W. 1986. Water flow and solute transport processes in the unsaturated zone. Water Resources Research 22: 89S-108S. https://doi.org/10.1029/WR022i09Sp0089S

Nuutinen, V., Butt, K.R., Hyväluoma, J., Ketoja, E. \& Mikola, J. 2017. Soil faunal and structural responses to the settlement of a semi-sedentary earthworm Lumbricus terrestris in an arable clay field. Soil Biology \& Biochemistry 115: 285-296. https://doi. org/10.1016/j.soilbio.2017.09.001

Nuutinen, V., Butt, K.R. \& Jauhiainen, L. 2011. Field margins and management affect settlement and spread of an introduced dew worm (Lumbricus terrestris L.) population. Pedobiologia 54S, S167-S172. https://doi.org/10.1016/j.pedobi.2011.07.010

Nuutinen, V., Nieminen, M. \& Butt, K.R. 2006. Introducing deep burrowing earthworms (Lumbricus terrestris L.) into arable heavy clay under boreal conditions. European Journal of Soil Biology 37: S269-S274. https://doi.org/10.1016/j.ejsobi.2006.07.022

Peng, X., Horn, R. \& Smucker, A. 2007. Pore shrinkage dependency of inorganic and organic soils on wetting and drying cycles. Soil Science Society of America Journal 71: 1095-1104. https://doi.org/10.2136/sssaj2006.0156

Pires, L.F., Borges, J.A.R., Rosa, J.A., Cooper, M., Heck, J., Passoni, S. \& Roque, W.L. 2017. Soil structure changes induced by tillage systems. Soil \& Tillage Research 165: 66-79. https://doi.org/10.1016/j.still.2016.07.010

Pirinen, P., Simola, H., Aalto, J., Kaukoranta, J.-P., Karlsson, P. \& Ruuhela, R. 2012. Climatological statistics of Finland 1981-2010. Reports 2012:1. Finnish Meteorological Institute, Helsinki. 83 p.

Reynolds, W.D. \& Elrick, D.E. 1991. Determination of hydraulic conductivity using a tension infiltrometer. Soil Science Society of America Journal 55: 633-639. https://doi.org/10.2136/sssaj1991.03615995005500030001x

Ritsema, C.J. \& Dekker, L.W. 2000. Preferential flow in water repellent sandy soils: principles and modeling implications. Journal of Hydrology 231-232: 308-319. https://doi.org/10.1016/S0022-1694(00)00203-1

Sandin, M., Koestel, J., Jarvis N. \& Larsbo, M. 2017. Post-tillage evolution of structural pore space and saturated and near-saturated hydraulic conductivity in a clay loam soil. Soil \& Tillage Research 165: 161-168. https://doi.org/10.1016/j.still.2016.08.004

Schwen, A., Bodner, G., Scholl, P., Buchan, G.D. \& Loiskandl, W. 2011. Temporal dynamics of soil hydraulic properties and the water-conducting porosity under different tillage. Soil \& Tillage Research 113: 89-98. https://doi.org/10.1016/j.still.2011.02.005

Shouse, P.J. \& Mohanty, B.P. 1998. Scaling of near-saturated hydraulic conductivity measured using disc infiltrometers. Water Resources Research 34: 1195-1205. https://doi.org/10.1029/98WR00318

Sippola, J. 1974. Mineral composition and its relation to texture and to some chemical properties in Finnish subsoils. Annales Agriculturae Fenniae 13: 169-234.

Stroud, J.L., Irons, D., Carter, J.E., Watts, C.W., Murray, P.J., Norris, S.L. \& Whitmore, A.P. 2016. Lumbricus terrestris middens are biological hotspots in a minimum tillage arable ecosystems. Applied Soil Ecology 105: 31-35. https://doi.org/10.1016/j.apsoil.2016.03.019

Strudley, M.W., Green, T.R. \& Ascough II, J.C. 2008. Tillage effects on soil hydraulic properties in space and time: State of the science. Soil \& Tillage Research 99: 4-48. https://doi.org/10.1016/j.still.2008.01.007

Tofteng, C., Hansen, S. \& Jensen, H.E. 2002. Film and pulse flow in artificial macropores. Hydrology Research 33: 263-274. https://doi.org/10.2166/nh.2002.0007

Tuller, M. \& Or, D. 2002. Unsaturated hydraulic conductivity of structured porous media: A review of liquid configuration-based models. Vadose Zone Journal 1: 14-37. https://doi.org/10.2113/1.1.14 
Tuller, M., Or, D. \& Dudley, L.M. 1999. Adsorption and capillary condensation in porous media: Liquid retention and interfacial configurations in angular pores. Water Resources Research 35: 1949-1964. https://doi.org/10.1029/1999WR900098

Turtola, E., Alakukku, L., Uusitalo, R. \& Kaseva, A. 2007. Surface runoff, subsurface drainflow and soil erosion as affected by tillage in a clayey Finnish soil. Agricultural and Food Science 16: 332-351. https://doi.org/10.2137/145960607784125429

Uusitalo, R., Lemola, R. \& Turtola, E. 2018. Surface and subsurface phosphorus discharge from a clay soil in a nine-year study comparing no-till and plowing. Journal of Environmental Quality 47: 1478-1486. https://doi.org/10.2134/jeq2018.06.0242

Warrick, A.W. \& Nielsen, D.R. 1980. Spatial variability of soil physical properties in the field. In: Hillel, D. (ed.). Applications of soil physics. New York: Academic Press. p. 319-344. https://doi.org/10.1016/B978-0-12-348580-9.50018-3

Watson, K. \& Luxmoore, R. 1986. Estimating macroporosity in a forest watershed by use of a tension infiltrometer. Soil Science Society of America Journal 50: 578-582. https://doi.org/10.2136/sssaj1986.03615995005000030007x

Westfall, P.H. 1997. Multiple Testing of General Contrasts Using Logical Constraints and Correlations. Journal of the American Statistical Association 92: 299-306. https://doi.org/10.1080/01621459.1997.10473627

Wooding, R.A. 1968. Steady infiltration from a shallow circular pond. Water Resources Research 4: 1259-1273. https://doi. org/10.1029/WR004i006p01259

Zhou, X., Lin, H.S. \& White, E.A. 2008. Surface soil hydraulic properties in four soil series under different land uses and their temporal changes. Catena 73: 180-188. https://doi.org/10.1016/j.catena.2007.09.009 